Araştırma Makalesi / Research Article

Peyzaj Mimarlığı /

Landscape Architecture

DOI: 10.21597/jist.517744
Iğdır Üniversitesi Fen Bilimleri Enstitüsü Dergisi, 9(4): 2266-2275, 2019

Journal of the Institute of Science and Technology, 9(4): 2266-2275, 2019

ISSN: 2146-0574, eISSN: 2536-4618

\title{
Evaluation of Schoolyards with Ecological Indicators: Kilis Case, Turkey
}

\author{
Murat YUCEKAYA ${ }^{1}$, Ahmet Salih GUNAYDIN ${ }^{2 *}$, Saliha TASCIOGLU ${ }^{3}$, Demet DEMIROGLU ${ }^{4}$
}

\begin{abstract}
Schoolyards are important components of open-green spaces that shape the physical structure of cities and contribute to citizens from ecological, social and cultural perspectives. These areas are potential educational environments where children and young people can develop their physical, social, emotional and mental skills, and they also act as the key actors to acquire environmental awareness. Designing these areas according to some ecological indicators to have better open-green field qualifications for school gardens in the cities and better relationships with nature is extremely important for contributing to the urban ecosystem and the multifaceted development of the users. The most important indicators are green field ratio, naturalness value of the plants used and vegetation variety. This study examines the open and green areas of 58 schools (8 kindergartens, 36 primary schools, 14 high schools) in Kilis city center within the framework of these indicators. The results show that the amount of open-green areas per person in all schools is below the standard. In the study area, primary schools have the least ratio of green areas and the least amount of green areas per person while high schools have the highest ratio of green spaces. The average naturalness score in all schools is over $60 \%$, but vegetation diversity in schoolyards is insufficient. As a result of the study, it was determined that schoolyards in the city have deficiencies regarding their contribution to urban ecosystem, healthy development of children / young people and establishing relations with nature. So, some suggestions were produced in this context.
\end{abstract}

Key Words: Ecological indicator, Kilis. Open-green areas, Schoolyard

\section{Okul Bahçelerinin Ekolojik Göstergelere Göre Değerlendirilmesi: Kilis Kenti Örneği}

ÖZET: Hızlı kentleşme ile birlikte değişen yaşam koşulları, kent kullanıcılarını ve aynı zamanda çocukların oyun alanlarını da olumsuz etkilemektedir. Günümüzde artan yapı yoğunluğu, trafik ve kentlerdeki göç alımı ile kentlerde değişen insan profiline bağlı olarak azalan güven duygusu, okul çağındaki çocukların sokak ve çevreyle olan bağlantısını koparmıştır. Ayrıca kentlerde açık ve yeşil alanların azalması nedeniyle çocukların oyun alanları kısıtlanırken, eğitim alanları içerisinde bulunan okul bahçeleri de bu açığı kapatmak amacıyla daha fazla önem kazanmıştır. Çocukların ve gençlerin çevre bilinci kazanma noktasında da önemli aktörlerden biri olan okul bahçelerinin ekolojik bazı göstergelere göre düzenlenmesi son derece önemlidir. Bu göstergelerden en önemlileri; yeşil alan oranları, kullanılan bitkilerin doğallık değerleri ve alanlardaki bitki örtüsü çeşitliliğidir. Çalışmanın amacı Kilis kent merkezinde bulunan okul bahçelerinin söz konusu bu göstergelere göre değerlendirilmesidir. Çalışmada Kilis kent merkezinde yer alan 8 anaokulunun, 36 ilköğretim okulunun ve 14 lisenin açık ve yeşil alanları değerlendirilmiştir. Çalışma alanında yeşil alan oranı ve kişi başına düşen yeşil alan miktarının en az olduğu eğitim kurumları ilköğretimler; en fazla olduğu kurumlar ise liseler olarak belirlenmiştir. Tüm okullardaki ortalama doğallık değeri \% 40’ın üzerinde olup; okul bahçelerindeki bitki örtüsü çeşitliliğinin yeterli olmadığı sonucuna varılmıştır.

Anahtar Kelimeler: Ekolojik gösterge, Kilis. Açık-yeşil alanlar, Okul bahçeleri

\footnotetext{
${ }^{1}$ Murat YUCEKAYA (Orcid ID: 0000-0003-2072-712X), Nevşehir Hacı Bektaş Veli University, Faculty of Engineering and Architecture, Department of Landscape Architecture, Nevşehir, Turkey

2 Ahmet Salih GUNAYDIN (Orcid ID: 0000-0001-5799-0445), Inonu University, Faculty of Fine Arts and Design, Department of Landscape Architecture, Malatya,Turkey

${ }^{3}$ Saliha TASCIOGLU (Orcid ID: 0000-0002-3986-4207), Kilis 7 Aralik University, Technical Sciences Vocational High School, Program of Landscape and Ornamental Plants, Kilis, Turkey

${ }^{4}$ Demet DEMIROGLU (Orcid ID: 0000-0002-3934-5319), Kilis 7 Aralik University, Faculty of Engineering-Architecture, Department of Landscape Architecture, Kilis, Turkey

*Sorumlu Yazar / Corresponding Author: Ahmet Salih GÜNAYDIN, ahmetsalihgunaydin@gmail.com 


\section{INTRODUCTION}

Urban open-green spaces are one of the main community lands that show and shape the physical structure of a city and are an element of balance that integrate the usage of other areas (Gül and Küçük, 2001), and these spaces make a significant contribution to residents in terms of ecological, social and cultural perspectives. They enhance social interaction and social cohesion / integrity / solidarity and strengthen the sense of community (Zhou and Rana, 2012). Green spaces, which create escape points for people to breathe in the cities that grow without an identity, can have positive effects on integration with nature, meeting active and passive recreation needs and human health (Çetinkale Demirkan, 2019). In addition, they also provide help in reducing drug use, drug addiction and crime rates in that young people spend their leisure time in the activity spaces designed for them (UN-HABITAT, 2008).

Schoolyards classified under "Semi-Private Open-Green Spaces" class (Gül and Küçük, 2001) are potential areas for providing all the benefits of the spaces outlined above. In many parts of Europe and America, schoolyards are designed in connection with urban open-green spaces.

School gardens are important environments where children can improve their physical, social, emotional and mental skills. In fact, studies show that a balanced physical activity in open air is two or three times more useful than that performed indoors (Andersen et al., 2015). It is a known fact that school-age children and young people are more interested in physical activity. In this sense, green spaces are known to promote physical activity in the school environment by facilitating open and flexible play conditions (Martensson et al., 2014). Research shows that in outdoor activities students integrate mathematics, science, grammar and other skills with their close environments through their five senses and that they learn better (Şişman and Gültürk, 2011).

Schoolyards have great value with their outdoor environment, but they also have the quality of being an invaluable observation area for children living in limited areas and have minimal contact with nature (Gök, 2012). These areas help students have direct experiences, and develop new knowledge, skills and values besides their role in creating an experimental learning environment (Bowker and Tearle, 2007). They also help students have an idea about living organisms, plants and environment, where many physical and chemical events take place (Erdönmez, 2007). At this point, the plants in these gardens, come to fore as important living materials that offer different play opportunities and improve their creativity in a positive way as well as ensuring that children are intertwined with nature (Acar, 2003). School gardens, where children spend most of their time and are a part of school environments, can contribute to their development by creating suitable spaces for children (Çetinkale Demirkan and Sandal Erzurumlu, 2018). Bowker and Tearle (2007) emphasized that schoolyards are potential areas that help children have deeper ecological understanding and thus, enable them to approach environmental problems and solutions with greater awareness. In this sense, the experience and information that children gain by playing and participating are of great importance (Erdönmez, 2007)

In this context, the green field ratio of the schoolyards, the natural value of the vegetation species used in the gardens and vegetation variety are important in students' improving their environmental knowledge, making observations and recognizing the local plants. This study examines the schoolyards in Kilis city center within the framework of these criteria. 


\section{MATERIALS AND METHOD}

The study was conducted in schoolyards in Kilis city center. Kilis is located in the southwestern part of the Gaziantep Plateau in the Southeastern Anatolia Region, extending between the Hatay-Maras direction and the Euphrates River. This geography, covering an area of 1.521 $\mathrm{km}^{2}$, is between $36^{\circ}$ north latitude and $32^{\circ}$ east longitude, surrounded with Oğuzeli in the east, Islahiye in the west and north, Şahinbey in the north and northeast and the Syrian border in the south (Figure 1). Kilis province is located in the Mediterranean vegetation cover area according to Phytogeography (Altan, 2000).

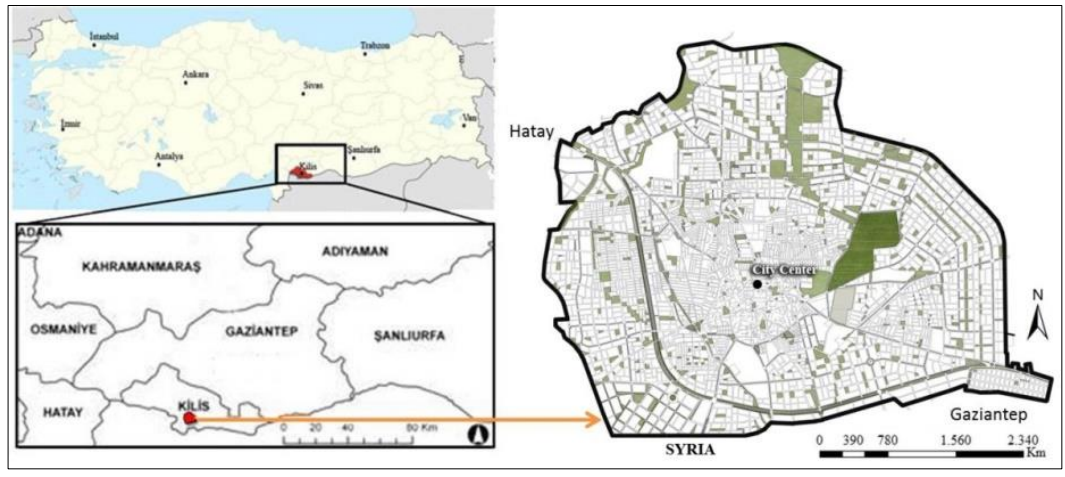

Figure 1. Geographical location of the research area

The research ground of the study is the schoolyards Kilis city. The study was carried out in 8 kindergartens, 36 elementary schools and 14 high schools in Kilis city center (Figure 2). The number of students in 58 educational institutions in Kilis city center is 24.289 (Kilis Provincial Directorate of National Education, 2017). Total educational area including building and garden areas are $342.815 \mathrm{~m}^{2}$. The study consists of three stages including data collection, analysissynthesis and evaluation stages. In the first stages of data collection, the school locations in the parcel maps were marked on the last current Kilis city map (Kilis Municipality, 2017).

In the second stage, the firm ground, building space, green area ratios and the amount of green area per student using the number of students obtained from the Provincial Directorate of National Education (Kilis Provincial Directorate of National Education, 2017) were determined. Then, the existing plant life in the green areas in the related schoolyards was determined. To determine the local plant species in Kilis, the studies conducted by Yaltırık 1993, Ürgenç 1990 and Altan 2000 were utilized.

In the synthesis stage, the naturalness value of a given area was determined by comparing the total number of natural plants to the sum of all plants. Then, vegetation cover structural diversity (tree-shrub, shrub, ground cover and clutchingclimbing plants) was determined. Since the vegetation period is active during spring and summer, the field studies were carried out at these months in 2017. In the last stage, the number of students in kindergartens, primary schools and high schools, the firm ground ratio (\%), building area ratio $(\%)$, green area ratio $(\%)$, amount of green area per student $\left(\mathrm{m}^{2}\right)$ and naturalness value obtained in 2nd stage (\%) and vegetation diversity were tabulated and evaluated within the scope of the study. 


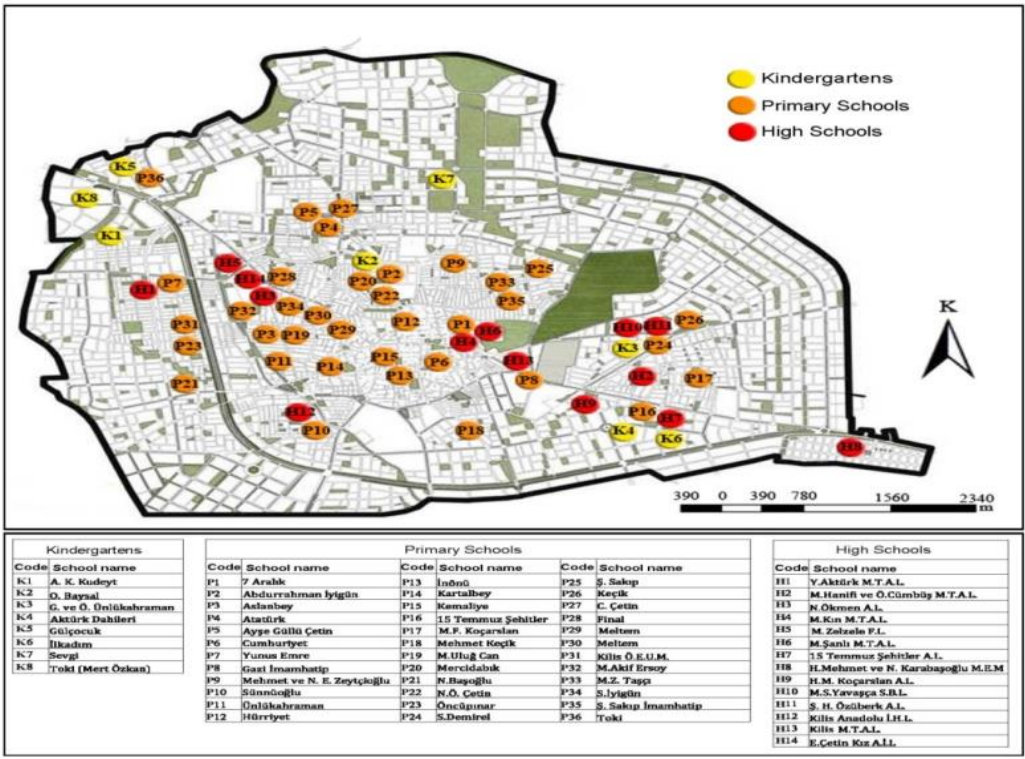

Figure 2. Schools in the research area

\section{RESULTS AND DISCUSSION}

\section{Evaluation of Kindergartens}

The green area ratio of the 8 kindergartens in which the study is conducted is $0-85.9 \%$; and the green area per student varies between 0 and $50 \mathrm{~m}^{2}$. While Aktürk (K4) and İlkadım (K6) have no green space, Atilla Kamil Kudeyt Kindergarten (K1) is the one with the highest amount of green space per student. Kindergarten with the highest firm ground rate is Mert Özkan Kindergarten (K8). Aktürk Kindergarten (K4) and İlkadım Kindergarten (K6) are formed entirely from the building space; they have no open-green space. When all kindergartens are evaluated together, the average hard-soil rate is $32.3 \%$, the average green space rate is $28.2 \%$ and the green space per student is $9.3 \mathrm{~m}^{2}$ (Table 1). The average naturalness score of kindergartens is $40.3 \%$. Kindergarten with the highest naturalness score is Osman Baysan Kindergarten with $89.1 \%$. Kindergartens have mainly two types of vegetation (trees and shrubs). There are no ground cover and climbing plants (Table 1).

Table 1. Evaluation of kindergarten yards

\begin{tabular}{|c|c|c|c|c|c|c|c|c|c|c|c|}
\hline \multirow{2}{*}{$\begin{array}{c}\text { School } \\
\text { Number }\end{array}$} & \multirow{2}{*}{$\begin{array}{c}\text { Number of } \\
\text { Students }\end{array}$} & \multirow{2}{*}{$\begin{array}{c}\text { Building } \\
\text { Ratio } \\
(\%)\end{array}$} & \multirow{2}{*}{$\begin{array}{c}\text { Firm Ground } \\
\text { Ratio } \\
(\%)\end{array}$} & \multirow{2}{*}{$\begin{array}{c}\text { Firm Ground } \\
\text { Per Student } \\
\left(\mathrm{m}^{2}\right)\end{array}$} & \multirow{2}{*}{$\begin{array}{c}\text { Green } \\
\text { Area Ratio } \\
(\%)\end{array}$} & \multirow{2}{*}{$\begin{array}{c}\text { Green Area } \\
\text { Per Student } \\
\left(\mathbf{m}^{2}\right)\end{array}$} & \multirow{2}{*}{$\begin{array}{c}\text { Naturaln } \\
\text { ess Value } \\
(\%)\end{array}$} & \multicolumn{4}{|c|}{ Vegetation Diversity } \\
\hline & & & & & & & & V1* & $\mathrm{V} 2 * *$ & V3*** & $\mathrm{V} 4 * * * *$ \\
\hline$\overline{\mathbf{K 1}}$ & 91 & 9.5 & 4.6 & 2.7 & 85.9 & 50 & 68 & 169 & 17 & 0 & 0 \\
\hline $\mathbf{K} 2$ & 114 & 22.6 & 17.4 & 3.4 & 60 & 11.6 & 89.1 & 141 & 25 & 0 & 0 \\
\hline K3 & 203 & 15 & 44.8 & 7.8 & 40.2 & 7 & 85.4 & 181 & 58 & 0 & 0 \\
\hline K4 & 14 & 100 & 0 & 0.0 & 0 & 0 & 0 & 0 & 0 & 0 & 0 \\
\hline K5 & 20 & 39.7 & 56 & 42.3 & 4.3 & 3.25 & 0 & 22 & 7 & 0 & 0 \\
\hline K6 & 15 & 100 & 0 & 0.0 & 0 & 0 & 0 & 0 & 0 & 0 & 0 \\
\hline K7 & 87 & 35.7 & 56.3 & 11.3 & 8 & 1.6 & 45.6 & 17 & 29 & 0 & 0 \\
\hline K8 & 165 & 47.4 & 44 & 2.0 & 8.6 & 0.69 & 35 & 11 & 9 & 0 & 0 \\
\hline TOTAL & 709 & 46.2 & 27.9 & 8.7 & 25.8 & 9.3 & 40.4 & 541 & 145 & 0 & 0 \\
\hline
\end{tabular}

*: Number of Trees-small trees, **: Number of Shrubs, ***: Number of Ground cover, Number of clutching-climbing plants 
Table 2. Evaluation of Primary Schools Gardens

\begin{tabular}{|c|c|c|c|c|c|c|c|c|c|c|c|}
\hline \multirow{2}{*}{$\begin{array}{c}\text { School } \\
\text { Number }\end{array}$} & \multirow{2}{*}{$\begin{array}{c}\text { Number } \\
\text { of } \\
\text { Students }\end{array}$} & \multirow{2}{*}{$\begin{array}{c}\text { Building } \\
\text { Ratio } \\
(\%)\end{array}$} & \multirow{2}{*}{$\begin{array}{c}\text { Firm } \\
\text { Ground } \\
\text { Ratio (\%) }\end{array}$} & \multirow{2}{*}{$\begin{array}{c}\text { Firm Ground } \\
\text { Per Student } \\
\left(\mathbf{m}^{2}\right)\end{array}$} & \multirow{2}{*}{$\begin{array}{c}\text { Green } \\
\text { Area Ratio } \\
(\%)\end{array}$} & \multirow{2}{*}{$\begin{array}{c}\text { Green Area } \\
\text { Per Student } \\
\left(\mathbf{m}^{2}\right)\end{array}$} & \multirow{2}{*}{$\begin{array}{c}\text { Naturalness } \\
\text { Value } \\
(\%)\end{array}$} & \multicolumn{4}{|c|}{ Vegetation Diversity } \\
\hline & & & & & & & & V1* & $\mathrm{V} 2 * *$ & $\mathrm{~V} 3 * * *$ & $\mathrm{~V} 4 * * * *$ \\
\hline P1 & 332 & 28.1 & 62.5 & 4.5 & 9.4 & 0.67 & 100 & 70 & 0 & 0 & 0 \\
\hline $\mathbf{P 2}$ & 310 & 24.4 & 65.6 & 5.2 & 10 & 0.8 & 67.3 & 42 & 4 & 0 & 0 \\
\hline P3 & 347 & 34.8 & 34.5 & 2.0 & 30.7 & 1.8 & 92.5 & 54 & 0 & 0 & 0 \\
\hline P4 & 340 & 12.5 & 21.1 & 3.2 & 66.4 & 10.2 & 70 & 215 & 0 & 0 & 0 \\
\hline P5 & 222 & 18 & 57.6 & 9.4 & 24.4 & 4 & 81.6 & 96 & 2 & 0 & 0 \\
\hline P6 & 387 & 28.4 & 47.3 & 3.9 & 24.3 & 2 & 96 & 75 & 0 & 0 & 0 \\
\hline P7 & 897 & 7 & 43.3 & 4.1 & 49.7 & 4.7 & 88.8 & 270 & 34 & 0 & 0 \\
\hline P8 & 368 & 19.3 & 63.4 & 6.2 & 17.3 & 1.7 & 84.7 & 99 & 32 & 0 & 0 \\
\hline P9 & 414 & 16.5 & 80 & 11.4 & 3.5 & 0.5 & 68 & 44 & 0 & 0 & 0 \\
\hline P10 & 129 & 15 & 33.5 & 3.3 & 51.5 & 5 & 98.6 & 181 & 173 & 0 & 0 \\
\hline P11 & 203 & 27.7 & 34.3 & 7.4 & 38 & 8.2 & 88.8 & 196 & 0 & 0 & 0 \\
\hline P12 & 723 & 34.1 & 54.9 & 2.9 & 11 & 0.59 & 59 & 78 & 17 & 0 & 0 \\
\hline P13 & 398 & 34.8 & 49.4 & 1.6 & 15.8 & 0.5 & 80 & 30 & 12 & 0 & 0 \\
\hline P14 & 719 & 39 & 46 & 2.5 & 15 & 0.8 & 70.1 & 53 & 34 & 0 & 0 \\
\hline P15 & 172 & 21.3 & 68 & 4.4 & 10.7 & 0.7 & 3.1 & 29 & 0 & 0 & 0 \\
\hline P16 & 1488 & 13.9 & 55.5 & 3.8 & 30.6 & 2.1 & 74.1 & 323 & 122 & 0 & 0 \\
\hline P17 & 545 & 20.2 & 57.1 & 3.3 & 22.7 & 1.3 & 100 & 151 & 0 & 0 & 0 \\
\hline P18 & 205 & 13.8 & 22.4 & 4.8 & 63.8 & 13.7 & 92.1 & 286 & 31 & 0 & 0 \\
\hline P19 & 903 & 24.6 & 52 & 3.8 & 23.3 & 1.7 & 82.2 & 113 & 22 & 0 & 0 \\
\hline P20 & 605 & 9.8 & 48.1 & 9.1 & 42.1 & 8 & 86.7 & 248 & 84 & 0 & 0 \\
\hline P21 & 542 & 14 & 40 & 3.2 & 46 & 3.7 & 91.3 & 161 & 0 & 0 & 0 \\
\hline P22 & 271 & 16 & 32.1 & 4.6 & 51.9 & 7.4 & 84.2 & 160 & 14 & 0 & 0 \\
\hline $\mathbf{P 2 3}$ & 157 & 17.3 & 32 & 8.0 & 50.7 & 12.7 & 79 & 81 & 0 & 0 & 0 \\
\hline P24 & 1095 & 16.8 & 45.4 & 5.9 & 37.8 & 4.9 & 87.6 & 495 & 64 & 0 & 0 \\
\hline P25 & 305 & 28.7 & 66.6 & 7.1 & 4.7 & 0.5 & 90.4 & 63 & 0 & 0 & 0 \\
\hline P26 & 388 & 18.4 & 50 & 4.1 & 31.6 & 2.6 & 82 & 286 & 31 & 0 & 0 \\
\hline P27 & 190 & 10 & 34.3 & 10.7 & 55.7 & 17.3 & 96.6 & 236 & 5 & 0 & 0 \\
\hline P28 & 194 & 0 & 0 & 0 & 0 & 0 & 0 & 0 & 0 & 0 & 0 \\
\hline P29 & 72 & 0 & 0 & 0 & 0 & 0 & 0 & 0 & 0 & 0 & 0 \\
\hline P30 & 81 & 0 & 0 & 0 & 0 & 0 & 0 & 0 & 0 & 0 & 0 \\
\hline P31 & 71 & 36 & 46.9 & 31.5 & 17.1 & 11.5 & 80 & 40 & 27 & 0 & 0 \\
\hline P32 & 768 & 17.5 & 78.4 & 5.7 & 4.1 & 0.3 & 15.6 & 21 & 11 & 0 & 0 \\
\hline P33 & 409 & 35.5 & 60 & 2.7 & 4.5 & 0.2 & 16.6 & 0 & 14 & 0 & 0 \\
\hline P34 & 395 & 24.7 & 61.4 & 6.6 & 13.9 & 1.5 & 98.8 & 116 & 47 & 0 & 0 \\
\hline P35 & 97 & 28.5 & 61.7 & 25.8 & 9.8 & 4.1 & 52.7 & 36 & 6 & 0 & 0 \\
\hline P36 & 1273 & 27.7 & 50.9 & 2.1 & 21.4 & 0.9 & 11.4 & 72 & 51 & 0 & 0 \\
\hline TOTAL & 16015 & 20.4 & 46.0 & 6 & 25.3 & 3.8 & 68.6 & 4420 & 837 & 0 & 0 \\
\hline
\end{tabular}

*: Number of Trees-small trees, $* *:$ Number of Shrubs, $* * *:$ Number of Ground cover, Number of clutching-climbing plants

\section{Evaluation of Primary Schools}

The total green space ratio of 36 primary schools is between $0.4-66.4 \%$; the firm ground ratio is between $0 \%$ and $80 \%$. The school with the highest green space rate is Atatürk Secondary School (P14); the school with the highest level of firm ground is Hac1 Mehmet and Nimet Erman Zeytçioğlu Primary School (I9). The number of 
schools with a firm ground rate above $50 \%$ or more is 17 . There are no open-green spaces in 3 primary schools. These schools are Meltem Primary School (P28), Final (P29) and Meltem Secondary School (P30). The amount of green space per student in primary schools varies between $0-17.3 \mathrm{~m}^{2}$. While the amount of green space per student in 14 schools is less than $1 \mathrm{~m}^{2}$, Cemil Çetin Primary School (P27) has the highest score per student. When all primary schools are evaluated together, the average firm ground rate is $46 \%$, the green area rate is $25.3 \%$, the amount of green area per student is $3.8 \mathrm{~m}^{2}$ (Table 2).

The average naturalness value of primary schools was determined to be $68.6 \%$. The school with the highest naturalness score is 7 Aralık Primary School (P1) with a rate of $100 \%$. Two types of vegetation (trees and shrubs) have been identified in primary schools. They have no ground cover and climbing plants (Table 2).

\section{Evaluation of High Schools}

The firm ground ratio of the 14 high schools is $18.4 \%-62 \%$; green area ratio varies between
$12.7 \%$ and $74.2 \%$. The high school with the highest level of firm ground is $\mathrm{H}$. Mehmet and $\mathrm{N}$. Karabaşoğlu High School (H8); the school with the highest rate of green areas is 15 Temmuz Şehitler Anatolian High School (H7). The green space per student in high schools varies between $1.6 \mathrm{~m}^{2}$ and $49.5 \mathrm{~m}^{2}$. The school with the lowest score is H. Mehmet and N.Karabaşoğlu High School (H8), and the one with the highest score is N. Ökmen Anatolian High School (H3). When all high schools are evaluated together, firm ground rate average is $37.5 \%$; green field average is $45.4 \%$; green space per student is $12.5 \mathrm{~m}^{2}$.

The average naturalness value of the high schools in the research area is $78 \%$; the school with highest naturalness score is $\mathrm{N}$. Ökmen Anatolian Teacher High School (H3) with 96.5\% and lowest score Yaşar Aktürk Vocational and Technical Anatolian High School (H1) with 30\%. Two types of vegetation were used in high schools (Table 3).

Table 3. Evaluation of High School Gardens

\begin{tabular}{|c|c|c|c|c|c|c|c|c|c|c|c|}
\hline \multirow[t]{2}{*}{ School Number } & \multirow{2}{*}{$\begin{array}{l}\text { Number of } \\
\text { Students }\end{array}$} & \multirow{2}{*}{$\begin{array}{c}\text { Building } \\
\text { Ratio } \\
(\%)\end{array}$} & \multirow{2}{*}{$\begin{array}{c}\text { Firm Ground } \\
\text { Ratio } \\
(\%)\end{array}$} & \multirow{2}{*}{$\begin{array}{c}\text { Firm Ground } \\
\text { Per Student } \\
\left(\mathbf{m}^{2}\right)\end{array}$} & \multirow{2}{*}{$\begin{array}{c}\text { Green } \\
\text { Area Ratio } \\
(\%)\end{array}$} & \multirow{2}{*}{$\begin{array}{c}\text { Green Area } \\
\text { Per Student } \\
\left(\mathbf{m}^{2}\right)\end{array}$} & \multirow{2}{*}{$\begin{array}{c}\text { Naturalnes } \\
\text { s Value } \\
(\%)\end{array}$} & \multicolumn{4}{|c|}{ Vegetation Diversity } \\
\hline & & & & & & & & $\mathrm{V} 1 *$ & $\mathrm{~V} 2^{* *}$ & $\mathrm{~V} 3 * * *$ & $\mathrm{~V} 4 * * * *$ \\
\hline H1 & 306 & 13.3 & 49.8 & 10.5 & 36.9 & 7.8 & 30 & 111 & 24 & 0 & 3 \\
\hline $\mathbf{H} 2$ & 465 & 6.9 & 21.7 & 3.6 & 71.4 & 11.7 & 90 & 276 & 35 & 0 & 0 \\
\hline $\mathbf{H 3}$ & 669 & 15.6 & 19.1 & 14.5 & 65.3 & 49.5 & 96.5 & 1888 & 41 & 0 & 0 \\
\hline H4 & 723 & 28.4 & 34.5 & 3.3 & 37.1 & 3.6 & 75 & 476 & 127 & 0 & 0 \\
\hline H5 & 279 & 16.5 & 47.3 & 17.4 & 36.2 & 13.3 & 75.1 & 365 & 85 & 0 & 0 \\
\hline H6 & 310 & 27.6 & 50 & 8.7 & 22.4 & 3.9 & 94.4 & 88 & 24 & 0 & 0 \\
\hline H7 & 700 & 7.4 & 18.4 & 2.4 & 74.2 & 9.8 & 87.2 & 395 & 58 & 0 & 0 \\
\hline H8 & 272 & 25.3 & 62 & 7.8 & 12.7 & 1.6 & 95 & 158 & 0 & 0 & 0 \\
\hline H9 & 591 & 14.5 & 30.4 & 4.2 & 55.1 & 7.6 & 79.3 & 177 & 2 & 0 & 0 \\
\hline H10 & 231 & 18.2 & 31.3 & 21.6 & 50.5 & 34.8 & 58.6 & 174 & 75 & 0 & 0 \\
\hline H11 & 621 & 12.8 & 54.9 & 12.6 & 32.3 & 7.44 & 65.7 & 246 & 37 & 0 & 0 \\
\hline H12 & 678 & 12.6 & 19.9 & 3.0 & 67.5 & 10.1 & 91.6 & 669 & 81 & 0 & 0 \\
\hline H13 & 1120 & 32.1 & 53.4 & 10.7 & 14.5 & 2.9 & 75.9 & 148 & 18 & 0 & 0 \\
\hline H14 & 600 & 8.5 & 32.5 & 5.9 & 59 & 10.8 & 77.1 & 242 & 42 & 0 & 0 \\
\hline TOTAL & 7565 & 17.1 & 37.5 & 9 & 45.4 & 12.5 & 78.0 & 5413 & 649 & 0 & 3 \\
\hline
\end{tabular}


The studies conducted in our country on school yards (Aksu and Demirel, 2011; Muhacir and Özalp, 2011; Özdemir, 2011; Şişman and Gültürk, 2011; Karadağ et.al. 2012, Karakaya and Kiper, 2013; Vural and Y1lmaz, 2018) focus primarily on primary school schoolyards. In addition, structural design elements and space usage of the schools were examined from the point of landscape design. In this study, the gardens of all schools (8 kindergartens, 36 primary schools and 14 high schools) in Kilis city center were investigated in terms of plant design elements. Thus, it is unique compared to other studies from this perspective

The space size and standards per person to be employed in educational institutions during zoning work in Turkey are determined in accordance with "Code on Construction of Spatial Plans" dated May 17, 2017 issued based on Zoning Law No 3194. According to this regulation, though there might be certain changes based on population size, while an average of 0.5 $\mathrm{m}^{2}-0.8 \mathrm{~m}^{2} /$ person is suggested for kindergartens and $2 \mathrm{~m}^{2} /$ person for primary, secondary and high schools, approximately $1500-4000 \mathrm{~m}^{2}$ space is allocated for kindergartens, 5000-8000 $\mathrm{m}^{2}$ for primary schools, 5000-10000 $\mathrm{m}^{2}$ for secondary schools and 6000-10000 $\mathrm{m}^{2}$ for high schools (Anonymous, 2017). These amounts are well below the recommended $25 \mathrm{~m}^{2}$ /person standard (Kelkit and Özel, 2003) ideal for schoolyards. As a matter of fact, the contribution of schoolyards to child development and education has led schoolyards to have important design principles in various countries in the world. For instance, $40 \mathrm{~m}^{2}$ space per student is allocated in Bulgaria, $30 \mathrm{~m}^{2}$ in Germany, $25 \mathrm{~m}^{2}$ in the UK, $20 \mathrm{~m}^{2}$ in the US, 16 $\mathrm{m}^{2}$ in Poland, and $15 \mathrm{~m}^{2}$ in France and China (Özyaba, 1998). In the study, green space per person is $9.3 \mathrm{~m}^{2}$ in kindergartens; $3.8 \mathrm{~m}^{2}$ in primary schools; $12.5 \mathrm{~m}^{2}$ in high schools. The amount of firm ground per person is $8.7 \mathrm{~m}^{2}$ in kindergartens; $6 \mathrm{~m}^{2}$ in primary schools, $9 \mathrm{~m}^{2}$ in high schools. These findings inform us that the amount of green space per student is $18 \mathrm{~m}^{2}, 9.8 \mathrm{~m}^{2}$ in primary schools, $21.5 \mathrm{~m}^{2}$ in high schools, which are insufficient.

In addition to schools' having insufficient open-green areas in the study area, they also have qualitative problems. In parallel researches conducted in our country (Gül and Küçük (2001; Algan and Uslu (2009); Kelkit and Özel (2003); Aksu and Demirel (2011); Muhacir and Özalp (2011); Özdemir (2011); Şişman and Gültürk (2011); Karadağ et al., 2012; Karakaya and Kiper, 2013; Vural and Y1lmaz, 2018), most of the garden areas of the schools in the city have concrete or asphalt surfaces. The schoolyards in question are insufficient at the level of structural and landscape-planting designs and consist of spaces with monotonous appearance. Çukur (2011) emphasized that the 0-6 age range, which is expressed as pre-school early childhood stage, acts as the most important building block for individual in becoming a healthy adult in the future and that the characteristic traits gained in this period are carried to the next stage of childhood and they contribute positively to personality formation. Çukur and Özgüner (2008) stated that nature consciousness and education should be conveyed to children through the use of natural elements and places in childhood and they need to cover 0-12 age range, especially early childhood periods. Therefore, kindergarten and primary school schoolyards should be viewed as educational places rather than as places that children spend their free times during the breaks, and the tools to be developed should support this kind of nature education. The places must be designed where the most natural learning environments are created by increasing the quality of life of a child, and where they can test what they 
have seen and heard and reinforce what they have learned in order to support activities that are essential for the social, emotional, cognitive, physical development and education of children. Natural elements such as trees and shrubs, herbaceous plants, lawns, flowers with vivid color, soil ground, tree stumps, rock fragments, sand and water should be used in these areas, and environmental education programs such as plant production, pet feeding, vegetable and fruit cultivation should be supported.

The amount of open-green space and their naturalness score and vegetation diversity per person in high schools in the research area are relatively higher than the other educational levels. However, it has been observed that these areas are not regulated within the framework of principles that will promote young people's physical abilities, education and training, social communication skills and health. Planning the recreational activities in high school gardens within the framework of these principles and reflecting these principles on the design is extremely important. Studies show that drug use is directly affected by how individuals make use of their free time. In a quasi-experimental study with a control group that observed a 12-year change of participants in Iceland, it was stated that planned leisure activities had a positive effect on young people and they decreased number of bad habits (Ertüzün et al., 2016).

When the vegetation diversity structure of the research areas is taken into consideration, it is seen that trees are mostly used while bushes, ground cover and climbers are not used that much. In addition, it is observed that the plants belonging to the same species are used quite frequently in the research area. These species are Pinus brutia, Robinia pseudoacacia, Cupressus sempervirens and Thuja orientalis. Since each species will need different types and forms of vegetation for housing, nutrition and breeding, the variety of vegetation structure in these areas is not capable of meeting all these needs of different living species. Thus, vegetation diversity to be formed in schoolyards will let one observe seasonal transitions and different species.

In recent years, especially in Europe and North America professionals working in the field of landscape design, are conducting researches that support habitat diversity and nature-based practices especially in the studies on schoolyards and playgrounds within the framework of ecological principles to increase the diversity of habitat and practices in support of using methods close to nature (Çukur and Özgüner, 2008). The benefits (educational, social, physical, and cultural) of schoolyard designs that include ecological diversity and wildlife have been documented in many studies (Louv, 2010). Therefore, the use local natural plants such as Pistacia terebinthus, Pistacia lentiscus, Cotinus coggygria Rhus coriaria, Quercus coccifera Cistus sp., Arbutus andrachne, Arbutus unedo Laurus nobilis Rosmarinus officinalis, Ceratonia siliqua, Paliurus spina-christi, Crataegus sp. should be increased in schoolyards designs. Thus, the chance of students to observe local plant and animal species on site will be increased. In addition, natural diversity can improve children's ability to form shape, color, dimension perception, and to form relationship between objects. Children will be able to gain awareness about the nature of their existence through observation of nature and comprehend the order of nature (Çukur, 2011). This way, a living environment will be created for different species in the areas; urban biodiversity, which is a high ecological quality indicator in the city, will increase. 


\section{CONCLUSIONS}

As a result, the multi-faceted contributions of the schoolyards to the city and the children have been revealed through scientific research. In order to increase these contributions, sufficient open-green areas should be allocated in the zoning plans by taking the needs of educational institutions and the group of students served into account, and these areas should be associated with other open and green areas in the city in zoning plans. The structural and landscape-planting designs of the schoolyards should be done based on the urban ecosystem and the educational, mental, social and physical development of children. In this context, this issue should be dealt with the professionals from the field of child education, development, planners and designers. In order to improve the existing schools within this framework, Provincial National Education Directorates, students, parents, working groups including landscape architects should come together to establish and implement structural and vegetative landscape projects within the framework of related standards.

\section{REFERENCES}

Acar H, 2003. Çocuk Oyun Alanlarında Kullanıcıların Bitki Tercihlerinin Belirlenmesi Üzerine Bir Araştırma: Trabzon Kenti Örneği. Karadeniz Technical University Institute of Natural and Applied Sciences, Master Thesis (Printed)

Aksu ÖV, Demirel Ö, 2011. Trabzon Kenti İlköğretim Okul Bahçelerinde Tasarım ve Alan Kullanımları. Süleyman Demirel University Journal of Forest Faculty. 12:40-46.

Algan H, Uslu C, 2011. İlköğretim Okul Bahçelerinin Tasarlanmasına Paydaş Katılımı: Adana Örneği. Akdeniz University Journal of Agricultural Faculty, 22(2): 129-140. Antalya.

Altan T, 2000. Doğal Bitki Örtüsü. Cukurova University Agricultural Faculty General Publication No: 235, pp. 73-141, Adana-Turkey.
Anonymous 2017. T.C. Official Gazette, No: 30069. Mekânsal Planlar Yapım Yönetmeliğinde Değişiklik Yapılmasına Dair Yönetmelik, 2017.

Andersen HB, Klinker CD, Toftager M, Pavlowski CS, Schipperijn J, 2015. Objectively Measured Differences in Physical Activity in Five Types of Schoolyard Area. Landscape and Urban Planning, 134: 83-92.

Bowker R. Tearle P, 2007. Gardening as a learning environment: A study of children's perceptions and understanding of school gardens as part of an international project. Learning Environment Research, 10: 83-100.

Çetinkale Demirkan, G., 2019. İyileştirici bahçeler ve tasarım kriterlerinin değerlendirilmesi. Turkish Journal of Agriculture-Food Science and Technology, 7(1): 148-151

Çetinkale Demirkan, G., Sandal Erzurumlu, G., 2018. Niğde İlindeki İlkokul Bahçelerinin Değerlendirilmesi. II. Uluslararası Multidisipliner Çalışmalar Kongresi, Bildiri Kitabı, Mimarlık, Planlama ve Tasarım, Akademisyen Kitapevi. ISBN: 978-605-258-096-7

Çukur D, Özgüner H, 2008. Kentsel Alanda Çocuklara Doğa Bilinci Kazandırmada Oyun Mekanı Tasarımının Rolü. Süleyman Demirel University Journal of Forest Faculty. 2: 177-187.

Çukur D, 2011. Okul Öncesi Çocukluk Döneminde Sağlıklı Gelişimi Destekleyici Dış Mekan Tasarımı Süleyman Demirel University Journal of Forest Faculty. 12: 70-76

Erdönmez İMÖ, 2007. İlköğretim Okul Bahçelerinde Peyzaj Tasarım Normları, Istanbul University Journal of Forest Faculty, 57 (1): 108-120.

Ertüzün E, Uyaroğlu AK, Demirel B, Kocak E, 2016. Boş Zaman Aktivitelerinin Madde Bağımlılı̆̆ Sürecindeki Rolüne İlişkin Nitel Bir Çalışma. Hacettepe Journal of Sport Sciences, 27 (2): 4958.

Gök AZ， 2012. İlköğretim Okul Bahçelerinin Öğrencilerin Tercihleri Ve Doğa Bilinci Gelişimini Destekleyici Yaklaşımlar Doğrultusunda Tasarımı: Isparta Kenti Örneği. Süleyman Demirel University Institute of Natural and Applied Sciences, Master Thesis (Printed) 
Gül A, Küçük V, 2001. Kentsel Açık-Yeşil Alanlar ve Isparta Kenti Örneğinde İrdelenmesi. Süleyman Demirel University Journal of Forest Faculty. A (2): 27-48.

Karadağ AA, Mutlu S, Sayın Ş, 2012. Okul bahçelerinin oyun alanı olarak değeri: Düzce kenti örneği. Düzce University Journal of Forest Faculty, 8 (2): 45-56.

Karakaya B, Kiper T, 2013. Edirne kent merkezindeki bazı ilköğretim okul bahçelerinin peyzaj tasarım ilkeleri açısından mevcut durumunun belirlenmesi. Journal of Tekirdağ Agricultural Faculty, 10 (1): 59-71.

Kelkit A, Özel AE, 2003. A research on the determination of physical planning of school gardens in Çanakkale city. Pakistan Journal of Applied Sciences, 3 (4): 240-246.

Louv R, 2010. Last Child in The Woods, (Translation: Ceyhan Temürcü), Tübitak Publications. AnkaraTurkey

Kilis Municipality, 2017. 1/5000 scaled based map (2017) of Kilis Municipality. Directorate of Reconstruction and Urbanization of Kilis Municipality. Kilis.

Kilis Provincial Directorate of National Education, 2017. Number of students in educational institutions in Kilis city center in 2017

Martensson F, Jansson M, Johansson M, Raustorp A, Kylin M, Boldemann C, 2014. The Role of Greenery for Physical Activity Play at School Grounds. Urban Forestry and Urban Greening, 13 (1): 103-113.

Muhacir AES, Özalp YA, 2011. Artvin kenti ilköğretim okul bahçelerinin nitelik ve niceliksel durumunun coğrafi bilgi sistemleri kullanılarak belirlenmesi. Artvin Çoruh University Journal of Forest Faculty, 12 (2): 172-184.
Özyaba M, 1998. İlköğretim Okulları Açık Alan Tasarım İlkeleri ve Standartlarının Tespiti: Trabzon'da Bir Örnek Çalışma. Karadeniz Technical University Publications, Trabzon-Turkey.

Özdemir A, 2011. Okul Bahçesi Peyzaj Tasarım Anlayısındaki Değisim $\mathrm{Ve} \quad \mathrm{Bu}$ Değisimin Uygulamaya Yansımalarının Bartın Kenti Örneğinde İrdelenmesi. Bartın University Journal of Forest Faculty, 13 (19): 41-51

Şişman EE, Gültürk P, 2011. İlköğretim Okul Bahçelerinin Peyzaj Planlama ve Tasarim İlkeleri Açısından İncelenmesi: Tekirdağ Örneği. Journal of Tekirdağ Agricultural Faculty, 8 (3): 53-60.

UN-HABITAT, 2008. State of the World's Cities 2008/2009. London, UK: United Nations Human Settlements Programme. http://www.unhabitat.org.jo/en/inp/Upload/10505 6 Cover\%20page.pdf. (Date of access: 26 November 2018)

Ürgenç S, 1990. Genel Plantasyon ve Ağaçlandırma Tekniği. İstanbul University Publication No: 35, pp. 502-503, İstanbul-Turkey.

Vural H, Yilmaz S, 2018. Erzurum Kenti Okul Bahçelerinin Fiziki Yeterlilikleri. Turkish Journal of Agricultural and Natural Sciences, 5 (2): 109120.

Yaltırık F, 1993. Dendroloji II, Angiospermae (Kapalı Tohumlular) Chapter I. 2. Printing. Istanbul University Faculty of Forest Publication No: 420, Istanbul University Publication No: 3767, p: 256, Istanbul-Turkey

Zhou X, Rana MP, 2012. Social benefits of urban green space A conceptual framework of valuation and accessibility measurements, Management of Environmental Quality: An International Journal, 23 (2): 173-189. 